\title{
Multiband GaNAsP Quaternary Alloys
}

K. M. Yu, ${ }^{1}$ W. Walukiewicz, ${ }^{1}$ J.W. Ager III, ${ }^{1}$ D. Bour, ${ }^{3}$ R. Farshchi, ${ }^{1,2}$ O. D. Dubon,,${ }^{1,2}$ S. X. $\mathrm{Li}^{1,2}{ }^{1}$ I. D. Sharp, ${ }^{1,2}$ and E. E. Haller ${ }^{1,2}$

${ }^{I}$ Materials Sciences Division, Lawrence Berkeley National Laboratory, Berkeley, California 94720

${ }^{2}$ Department of Materials Science and Engineering, University of California, Berkeley, California 94720

${ }^{3}$ Applied Materials, Santa Clara, CA 95052

We have synthesized $\mathrm{GaN}_{\mathrm{x}} \mathrm{As}_{1-\mathrm{y}} \mathrm{P}_{\mathrm{y}}$ alloys $(\mathrm{x} \sim 0.3-1 \%$ and $\mathrm{y}=0-0.4)$ using nitrogen $\mathrm{N}$ ion implantation into GaAsP epilayers followed by pulsed laser melting and rapid thermal annealing techniques. As predicted by the band anticrossing model, the incorporation of $\mathrm{N}$ splits the conduction band $\left(\mathrm{E}_{\mathrm{M}}\right)$ of the $\mathrm{GaAs}_{1-\mathrm{y}} \mathrm{P}_{\mathrm{y}}$ substrate, and strong optical transitions from the valence band to the lower $\left(E_{-}\right)$and upper $\left(E_{+}\right)$conduction subbands are observed. The relative strengths of the $\mathrm{E}_{-}$and $\mathrm{E}_{+}$transition change as the localized $\mathrm{N}$ level $\mathrm{E}_{\mathrm{N}}$ emerges from the conduction band forming narrow intermediate band for $\mathrm{y}>0.3$. The results show that $\mathrm{GaN}_{\mathrm{x}} \mathrm{As}_{1-\mathrm{x}-\mathrm{y}} \mathrm{P}_{\mathrm{y}}$ alloys with $\mathrm{y}>0.3$ is a three band semiconductor alloy with potential applications for high-efficiency intermediate band solar cells.

PACS numbers: 71.20.Nr; 78.66.Fd; 61.72.Vv; 89.30.Cc 
Highly mismatched alloys (HMAs) are a recently developed class of semiconductor materials in which small fractions of electronegative (metallic) atoms are replaced by metallic (electronegative) atoms. The large electronegativity mismatch leads to drastic modification of the electronic structure. The most studied HMAs are group III$\mathrm{N}_{\mathrm{x}}-\mathrm{V}_{1-\mathrm{x}}$ (especially GaAsN) and group II- $\mathrm{O}_{\mathrm{x}}-\mathrm{VI}_{1-\mathrm{x}}$ alloys. [1-3] In our earlier work we have demonstrated that the electronic band structure of such HMAs is well described by the anticrossing interaction between localized $\mathrm{N}$ or $\mathrm{O}$ states and the extended states of the semiconductor matrix [3-5]. The interaction splits the conduction band into two nonparabolic subbands: $\mathrm{E}_{+}$and $\mathrm{E}_{\text {. }}$ The large modification of the electronic band structure profoundly affects the optical and electrical properties of these alloys. For example, in $\mathrm{GaN}_{\mathrm{x}} \mathrm{As}_{1-\mathrm{x}}$, the incorporation of a small amount of $\mathrm{N}$ in HMAs, leads to a large reduction of the fundamental band gap [1], an increase of the electron effective mass [6], improved donor activation efficiency for group VI donors [7,8], and the mutual passivation of the group IV donors and the nitrogen [9-11]. Comparably large band gap reductions have also been observed in other III- $\mathrm{N}_{\mathrm{x}}-\mathrm{V}_{1-\mathrm{x}}$ HMAs alloys such as GaNP, InNP and AlGaNAs [12-15]. The theoretical and experimental aspects of III-N-V alloys have been extensively investigated and have been reviewed recently in a series of articles $[1,2]$. In close analogy, the formation of group II-O-VI HMAs by partial substitution of group VI anions with electronegative $\mathrm{O}$ in II-VI compounds has also been recently demonstrated [16-18].

In most instances, e.g. $\mathrm{N}$ in $\mathrm{GaAs}$ or $\mathrm{O}$ in $\mathrm{CdTe}$, the localized states are located within the conduction band and consequently a relatively wide lower subband is formed through the anticrossing effect. This is manifested as a reduction of the energy band gap 
[18]. The conduction-band states associated with the $\mathrm{E}$. edge retain the extended $\mathrm{E}_{\mathrm{M}-\text {-like }}$ character and those at the $\mathrm{E}_{+}$edge have a more localized $\mathrm{E}_{\mathrm{N}}\left(\right.$ or $\left.\mathrm{E}_{\mathrm{O}}\right)$-like character. $\mathrm{A}$ narrow lower band can be formed only if the localized states lie well below the conduction band edge. In this case the E. subband states are of highly localized character and the $\mathrm{E}_{+}$subband states become more extended. This situation occurs in II-VI alloys for $\mathrm{O}$ in $\mathrm{ZnTe}, \mathrm{MnTe}, \mathrm{MgTe}$ and $\mathrm{Cd}_{1-\mathrm{y}} \mathrm{Mn}_{\mathrm{y}} \mathrm{Te}$ with $\mathrm{y} \geq 0.4$. We have demonstrated that in $\mathrm{ZnTe}$ and $\mathrm{Zn}_{1-\mathrm{y}} \mathrm{Mn}_{\mathrm{y}} \mathrm{Te}$ alloys the anticrossing interaction between the $\mathrm{E}_{\mathrm{O}}$ located about $0.2 \mathrm{eV}$ below the conduction band edge and the extended conduction band states leads to formation of a narrow E. band well separated from the higher lying $E_{+}$subband. [17]. The band of intermediate states modifies the absorption spectrum by adding two new absorption edges. $\mathrm{Zn}_{1-\mathrm{x}} \mathrm{Mn}_{\mathrm{x}} \mathrm{O}_{\mathrm{y}} \mathrm{Te}_{1-\mathrm{y}}$ can be made so that its absoption edges fall within the solar energy spectrum, making it well suited for proposed high efficiency intermediate band solar cells (IBSCs) concepts [19-21].

The potential technological importance of the multiband semiconductors raises the question if they can also be realized in group III- $\mathrm{N}_{\mathrm{x}}-\mathrm{V}_{1-\mathrm{x}}$ HMAs as well. In most III$\mathrm{V}$ compounds the localized $\mathrm{N}$ level lies above the conduction band edge. An exception is the $\mathrm{GaAs}_{1-\mathrm{y}} \mathrm{P}_{\mathrm{y}}$ alloy system in which N-level falls below the conduction band edge for $y>0.3$. Consequently the anticrossing interaction of the $\mathrm{N}$ states with the extended conduction band states in these GaAsP alloys is expected to result in the formation of a narrow band of intermediate states. This is supported by the observation that the fundamental bandgap in $\mathrm{GaN}_{\mathrm{x}} \mathrm{P}_{1-\mathrm{x}}$ is transformed from indirect to direct for $\mathrm{x}>0.005$. [22-24]. However, the novel band structure of $\mathrm{GaN}_{\mathrm{x}} \mathrm{As}_{1-\mathrm{x}-\mathrm{y}} \mathrm{P}_{\mathrm{y}}$ alloys has not been explored $[25,26]$ yet. In this paper we report the synthesis of quaternary $\mathrm{GaN}_{\mathrm{x}} \mathrm{As}_{1-\mathrm{x}-\mathrm{y}} \mathrm{P}_{\mathrm{y}}$ 
alloys using $\mathrm{N}^{+}$implantation in epitaxially grown GaAsP films followed by pulsed laser melting techniques. We demonstrate that $\mathrm{GaN}_{\mathrm{x}} \mathrm{As}_{1-\mathrm{x}-\mathrm{y}} \mathrm{P}_{\mathrm{y}}$ with $\mathrm{y}>0.3$ is a multiband system that can be exploited for the fabrication of IBSCs.

$\mathrm{GaN}_{\mathrm{x}} \mathrm{As}_{1-\mathrm{x}-\mathrm{y}} \mathrm{P}_{\mathrm{y}}$ layers were formed by $\mathrm{N}^{+}$implantation into $\sim 0.5 \mu \mathrm{m}$ thick $\mathrm{GaAs}_{1-}$ ${ }_{y} \mathrm{P}_{\mathrm{y}}(\mathrm{y}=0-0.35)$ epitaxial films grown by metalorganic chemical vapor deposition (MOCVD) on semi-insulating GaAs substrate. Sequential $\mathrm{N}^{+}$implants with energies of 80 and $33 \mathrm{keV}$ with doses of $7 \times 10^{15}$ and $2.4 \times 10^{15} \mathrm{~cm}^{-2}$, respectively, were used to create $\sim 0.2 \mu \mathrm{m}$ thick layers with a uniform $\mathrm{N}$ atomic concentration of $\sim 4.4 \times 10^{20} \mathrm{~cm}^{-3}(2$ mole percent). The implanted structures were subjected to pulsed-laser melting (PLM) in air using a $\mathrm{KrF}$ excimer laser $(\lambda=224 \mathrm{~nm})$ with pulse duration $\sim 30 \mathrm{~ns}$ and photon fluence at the sample between 0.2 and $0.4 \mathrm{~J} / \mathrm{cm}^{2}$. Both the ion implantation and PLM processes are inherently non-equilibrium. Using a pulsed excimer laser, the heavily-damaged layer caused by ion implantation can be melted and recrystallized on time scales on the order of $10^{-7} \mathrm{~s}$. Such rapid solidification prevents secondary phase formation even when the equilibrium solubility limit has been exceeded by orders of magnitude [27]. This combined ion beam and laser processing approach has been demonstrated as an effective approach to synthesize dilute semiconductor alloys including $\mathrm{GaN}_{\mathrm{x}} \mathrm{As}_{1-\mathrm{x}}$ and $\mathrm{Ga}_{1-\mathrm{x}} \mathrm{Mn}_{\mathrm{x}} \mathrm{As}$ $[28,29]$.

Residual damage in the $\mathrm{GaN}_{\mathrm{x}} \mathrm{As}_{1-\mathrm{x}-\mathrm{y}} \mathrm{P}_{\mathrm{y}}$ layers was removed by post-PLM rapid thermal annealing at $950^{\circ} \mathrm{C}$ for $10-150 \mathrm{sec}$ in flowing $\mathrm{N}_{2}$ ambient. The crystalline structure of the $\mathrm{GaN}_{\mathrm{x}} \mathrm{As}_{1-\mathrm{x}-\mathrm{y}} \mathrm{P}_{\mathrm{y}}$ samples was studied by channeling Rutherford backscattering spectrometry (c-RBS) and x-ray diffraction. The band gaps of the films were measured using photomodulated reflectance (PR) at room temperature. The values 
of the band gap and the line width were determined by fitting the PR spectra to the Aspnes third-derivative functional form. [30]

The good epitaxial quality of the $\mathrm{GaN}_{\mathrm{x}} \mathrm{As}_{1-\mathrm{x}}$ layer formed by $\mathrm{N}^{+}$-implantation followed by PLM $\left(0.4 \mathrm{~J} / \mathrm{cm}^{2}\right)$ and RTA $\left(950^{\circ} \mathrm{C}\right.$ for $\left.10-150 \mathrm{~s}\right)$ is confirmed by channeling RBS measurements [28]. Channeling-RBS further reveals that the melt-solid interface occurs at $\sim 200 \mathrm{~nm}$ below the surface. We found that $0.4 \mathrm{~J} / \mathrm{cm}^{2}$ laser pulses followed by RTA at $950^{\circ} \mathrm{C}$ for $150 \mathrm{sec}$ were the optimum conditions for GaAs [28], also worked well for GaAsP. Fig. 1 shows a series of photoreflectance $(\mathrm{PR})$ spectra from $\mathrm{GaAs}_{1-\mathrm{y}} \mathrm{P}_{\mathrm{y}}$ samples with $0 \leq \mathrm{y} \leq 0.38$ implanted with $2 \%$ of $N$. The energy gap, $E_{M}$ of as-grown $\mathrm{GaAs}_{1-\mathrm{y}} \mathrm{P}_{\mathrm{y}}$ and the $\mathrm{N}$ level $\mathrm{E}_{\mathrm{N}}$ are indicated in the figure. The PR spectrum from the $\mathrm{N}^{+}-$ implanted GaAs sample after PLM and RTA exhibit a strong, well-resolved interband transition from the valence band maximum to the lower subband $\mathrm{E}_{-}$at $\sim 1.24 \mathrm{eV}$. This location of E_ corresponds to $\sim 1 \%$ of substitutional N. incorporated in the GaAs lattice. This is in agreement with our previous work that using the PLM-RTA method, the N incorporation efficiency is $\sim 50 \%$, over five times higher than that observed in samples synthesized by RTA alone [28].

Similar to the case of GaAs, PR spectra from the $\mathrm{N}^{+}$-implanted $\mathrm{GaAs}_{1-\mathrm{y}} \mathrm{P}_{\mathrm{y}}$ samples $(y>0)$ also show two well resolved optical transitions $E_{-}$and $E_{+}$, distinctly different from the band gap transition. The locations of $\mathrm{E}_{+}$and $\mathrm{E}_{-}$vary as the $\mathrm{P}$ content increases. It is also important to note the change in the relative strength of these two transitions. In GaAs and in As-rich $\mathrm{GaAs}_{1-\mathrm{y}} \mathrm{P}_{\mathrm{y}}$ the $\mathrm{E}_{\text {_ }}$ transition is much stronger than $\mathrm{E}_{+}$transition. However as is seen in Fig. 1 the relative strength of the $\mathrm{E}_{+}$transitions increases with increasing $\mathrm{P}$ content and becomes stronger than E. for $\mathrm{y}>0.25$. 
This behavior can be easily explained by the band anticrossing (BAC) model, taking into account the much weaker dipole optical coupling of the valence band to $\mathrm{E}_{\mathrm{N}}$ compared with the coupling between the valence band and $\mathrm{E}_{\mathrm{M}}$. As is shown in Fig. 2 the

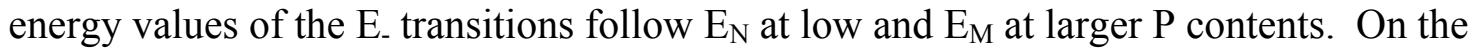
other hand $\mathrm{E}_{+}$transitions mostly follow $\mathrm{E}_{\mathrm{N}}$ at low and $\mathrm{E}_{\mathrm{M}}$ at lager $\mathrm{y}$. The character of the wavefunctions and thus also the strength of the optical transitions depend on the location of the $\mathrm{E}_{-}$and $\mathrm{E}_{+}$states relative to $\mathrm{E}_{\mathrm{N}}$ and $\mathrm{E}_{\mathrm{M}}$.

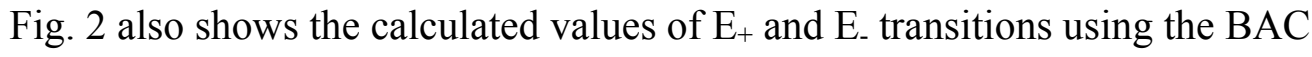
model assuming a $\mathrm{N}$ concentration of $0.3,1$ and $2 \%$ in the $\mathrm{GaN}_{\mathrm{x}} \mathrm{As}_{1-\mathrm{x}-\mathrm{y}} \mathrm{P}_{\mathrm{y}}$ layers [3-5]. The matrix element describing the coupling between $\mathrm{N}$ states and the extended states $\mathrm{C}_{\mathrm{NM}}$ is interpolated from that of $\mathrm{GaN}_{\mathrm{x}} \mathrm{As}_{1-\mathrm{x}}(2.7 \mathrm{eV})$ [3-5] and $\mathrm{GaN}_{\mathrm{x}} \mathrm{P}_{1-\mathrm{x}}(3.05 \mathrm{eV})$ [23].

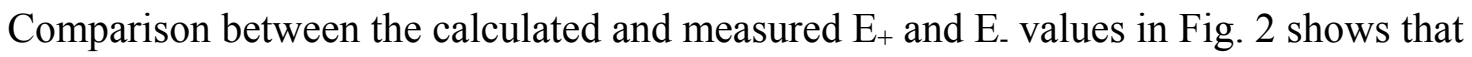
for $\mathrm{GaAs}_{1-\mathrm{y}} \mathrm{P}_{\mathrm{y}}$ layers with $\mathrm{y} \leq 0.12 \sim 1 \%$ of $\mathrm{N}$ is incorporated in the film $(\sim 50 \%$ of the total implanted $\mathrm{N}$ ). For $\mathrm{GaAs}_{1-\mathrm{y}} \mathrm{P}_{\mathrm{y}}$ layers with $\mathrm{y}>0.12$, the incorporated $\mathrm{N}$ concentration is smaller ( $\mathrm{x}=0.003$ ), and corresponds to an activation efficiency of $15 \%$ of the implanted $\mathrm{N}$. This may be due to the high density of the misfit dislocations in $\mathrm{GaAs}_{1-\mathrm{y}} \mathrm{P}_{\mathrm{y}}$ epitaxial layers coming from the large lattice mismatch with the GaAs substrate $(>0.4 \%$ for $\mathrm{y}>0.12$ ). These dislocations may act as a sink for the preferential segregation of $\mathrm{N}$ during the PLM and RTA processing steps.

The $\mathrm{GaN}_{\mathrm{x}} \mathrm{As}_{1-\mathrm{x}-\mathrm{y}} \mathrm{P}_{\mathrm{y}}$ with $\mathrm{y}>0.3$ is a multiple band gap system analogous to the ZnOTe system we previously reported [17]. As shown in Fig. 2, at a P content y $\geq 0.3$, $\mathrm{E}_{\mathrm{N}}$, lies below the direct conduction band minimum $\mathrm{E}_{\mathrm{M}}$ of the $\mathrm{GaAs}_{1-\mathrm{y}} \mathrm{P}_{\mathrm{y}}$ alloy; these are precisely the conditions that are required to make the narrow intermediate band required 
for a multiband solar cell. An upper limit to the $\mathrm{P}$ content is set by the appearance of an indirect band gap $\left(\mathrm{E}^{\mathrm{X}}<\mathrm{E}^{\Gamma}\right)$ at $\mathrm{y}>0.5$. Although only small fraction of $\mathrm{N}(\mathrm{x}=0.003)$ is incorporated in $\operatorname{GaAs}_{1-\mathrm{y}} \mathrm{P}_{\mathrm{y}}$ layers with $\mathrm{y}>0.2$ using the present implantation-PLM conditions, strong and distinctive optical transitions are indeed observed. As illustrated by the BAC calculation shown in Fig. 2, for a $\mathrm{GaN}_{\mathrm{x}} \mathrm{As}_{1-\mathrm{y}} \mathrm{P}_{\mathrm{y}}$ multiband semiconductor with $\mathrm{y}=0.4$ and an $\mathrm{x}=0.02 \mathrm{a} \mathrm{N}$ derived narrow band of extended states $\mathrm{E}$. is separated from the upper subband $\mathrm{E}_{+}$by about $0.8 \mathrm{eV}$. Three types of optical transitions are possible in this band structure: $0.8 \mathrm{eV}\left(\mathrm{E}_{-} \rightarrow \mathrm{E}_{+}\right), 1.5 \mathrm{eV}\left(\mathrm{E}_{\mathrm{V}} \rightarrow \mathrm{E}_{-}\right)$and $2.3 \mathrm{eV}\left(\mathrm{E}_{\mathrm{V}} \rightarrow \mathrm{E}_{+}\right)$. A theoretical maximum efficiency of between $55 \%$ and $60 \%$ for IBSCs fabricated using this alloy [19-21].

In conclusion we have synthesized $\mathrm{GaN}_{\mathrm{x}} \mathrm{As}_{1-\mathrm{y}} \mathrm{P}_{\mathrm{y}}$ with $\mathrm{y}=0$ to 0.4 using $\mathrm{N}^{+}$implantation followed by PLM and RTA techniques. With an implanted N concentration of $2 \%$, the $\mathrm{N}$ concentration incorporated in the As sublattice amounts to about $1 \%$ and $0.3 \%$ for films with $\mathrm{y} \leq 0.12$ and $\mathrm{y}>0.12$, respectively. $\mathrm{GaN}_{\mathrm{x}} \mathrm{As}_{1-\mathrm{y}} \mathrm{P}_{\mathrm{y}}$ with $\mathrm{y}>0.2$ clearly shows strong optical transitions corresponding to both the lower (E.) and upper $\left(\mathrm{E}_{+}\right)$ conduction subbands. This is in good agreement with the predictions of the BAC model. $\mathrm{GaN}_{\mathrm{x}} \mathrm{As}_{1-\mathrm{y}} \mathrm{P}_{\mathrm{y}}$ alloys with $\mathrm{y}>0.3$ have a three band structure making them suitable for testing the theoretical predictions of the highly-efficient intermediate band solar cell concept. Theoretical ideal efficiency for IBSC using the $\mathrm{GaN}_{0.02} \mathrm{As}_{0.58} \mathrm{P}_{0.4}$ is calculated to be $>55 \%$.

This work was supported by the Director's Innovation Initiative Program, National Reconnaissance Office and the Director, Office of Science, Office of Basic 
Energy Sciences, Division of Materials Sciences and Engineering, of the U. S.

Department of Energy under Contract No. DE-AC02-05CH11231. 


\section{REFERENCES}

1. see for example, Semiconductor Science and Technology 17, 2002, Special Issue: III-N-V Semiconductor Alloys.

2. Irina Buyanova and Weimin Chen ed., Physics and Applications of Dilute Nitrides, (Taylor \& Francis, New York, 2004).

3. W. Shan, W. Walukiewicz, J. W. Ager III, E. E. Haller, J. F. Geisz, D. J. Friedman, J. M. Olson, and S. R. Kurtz, Phys. Rev. Lett. 82, 1221(1999).

4. W. Walukiewicz, W. Shan, K. M. Yu, J. W. Ager III, E. E. Haller, I. Miotlowski, M. J. Seong, H. Alawadhi, and A. K. Ramdas, Phys. Rev. Lett. 85, 1552 (2000).

5. J. Wu, W. Shan, and W. Walukiewicz, Semicond. Sci. Technol. 17, 860 (2002).

6. C. Skierbiszewski, P. Perlin, P. Wišniewski, W. Knap, T. Suski, W. Walukiewicz, W. Shan, K. M. Yu, J.W. Ager, E.E. Haller, J.F. Geisz, and J.M. Olson, Appl. Phys. Lett. 76, 2409 (2000).

7. K. M. Yu, W. Walukiewicz, W. Shan, J. W. Ager III, J. Wu, E. E. Haller, J. F. Geisz, D. J. Friedman, J. M. Olson, and Sarah R. Kurtz, Phys. Rev. B61, R13337 (2000).

8. K. M. Yu, W. Walukiewicz, W. Shan, J. Wu, J. W. Ager III, E. E. Haller, J. F. Geisz, and M. C. Ridgway, Appl. Phys. Lett. 77, 2858 (2000).

9. K. M. Yu, W. Walukiewicz, J. Wu, D. Mars, D. R Chamberlin M. A. Scarpulla, O. D. Dubon, and J. F. Geisz, , Nature Materials 1, 185 (2002).

10. J. Wu, K. M. Yu, W. Walukiewicz, G. He, E. E. Haller, D. E. Mars, D. R Chamberlin, Phys. Rev. B 68, 195202 (2003). 
11. K. M. Yu, W. Walukiewicz, J. Wu, W. Shan, J. Beeman, M. A. Scarpulla, O. D. Dubon, M. C. Ridgway, D. E. Mars, and D. R Chamberlin, Appl. Phys. Lett. 83, 2844 (2003).

12. W. Shan, W. Walukiewicz, K. M. Yu, J. Wu, J. W. Ager, E. E. Haller, H. P. Xin, and C. W. Tu, Appl. Phys. Lett. 76, 3251 (2000).

13. W. G. Bi and C. W. Tu, J. Appl. Phys. 80, 1934 (1996).

14. W. Shan, W. Walukiewicz, K. M. Yu, J. W. Ager III, E. E. Haller, J. F. Geisz, D. J. Friedman, J. M. Olson, Sarah R. Kurtz, and K. Nauka, Phys. Rev. B62, 4211 (2000).

15. W. Shan, K. M. Yu, W. Walukiewicz, J. W. Ager, E. E. Haller and M. C. Ridgway, Appl. Phys. Lett. 75, 1410 (1999).

16. K. M. Yu, W. Walukiewicz, J. Wu, W. Shan, and J. W. Beeman, M. A. Scarpulla, O. D. Dubon, and P. Becla, J. Appl. Phys.95, 6232 (2004)

17. K. M. Yu, W. Walukiewicz, J. Wu, W. Shan, and J. W. Beeman, M. A. Scarpulla, O. D. Dubon, and P. Becla, Phys. Rev. Lett. 91, 246203 (2003).

18. K. M. Yu, W. Walukiewicz, M. A. Scarpulla, O. D. Dubon, W. Shan, J. Wu, J. W. Beeman, and P. Becla, IEE Proceedings-Optoelectronics 151 (5): 452-459, Oct. 2004 (IEE-Inst. Elec. Emg., Michael Faraday House, Six Hills Way, Stevenage, Hertford, SG1 2AY, ENGLAND).

19. M. Wolf, Proc. IRE, 48, 1246 (1960).

20. A. Luque, A. Marti., Phys. Rev. Lett., 78, 5014 (1997).

21. A. S. Brown, M. A. Green and R. P. Corkish, Physica E 14, 121, (2002). 
22. H. P. Xin, C. W. Tu, Y. Zhang, A. Mascarenhas, Appl. Phys. Lett. 76, 1267 (2000).

23. W. Shan, W. Walukiewicz, K. M. Yu, J. Wu, J. W. Ager III, E. E. Haller, H. P. Xin, and C. W. Tu, Appl. Phys. Lett. 76, 3251 (2000).

24. , J. Wu, W. Walukiewicz, K. M. Yu, J. W. Ager III, E. E. Haller, Y. G. Hong, H. P. Xin, and C. W. Tu, Phys. Rev. B65, 241303 (2002).

25. Yasuhiro Fujimoto, Hiroo Yonezu, Atsushi Utsumi, Kenji Momose, and Yuzo Furukawa, Appl. Phys. Lett. 79, 1306 (2001).

26. K. Momose, H. Yonezu, Y. Furukawa, A. Utsumi, Y. Yoshizumi, and S. Shinohara, J. Crystal Growth 251, 443 (2003).

27. C. W. White, S. R. Wilson, B. R. Appleton, F. W. Young Jr. , J. Appl. Phys. 51 $738(1980)$.

28. K. M. Yu, W. Walukiewicz, M. A. Scarpulla, O. D. Dubon, J. Jasinski, Z. Liliental-Weber, J. Wu, J. W. Beeman, M. R. Pillai, and M. J. Aziz, J. Appl. Phys. 94, $1043(2003)$

29. M. A. Scarpulla, O. D. Dubon, K. M. Yu, O. Monteiro, M. R. Pillai, M. J. Aziz, and M. C. Ridgway, Appl. Phys. Lett. 82, 1251 (2003).

30. D. E. Aspnes, Surf. Sci. 37, 418 (1973). 


\section{FIGURE CAPTIONS}

Fig. 1 Photoreflectance spectra from $2 \% \mathrm{~N}$ implanted $\mathrm{GaAs}_{1-\mathrm{y}} \mathrm{P}_{\mathrm{y}}(\mathrm{y}=0$ to 0.4$) \mathrm{PLM}$ at 0.4 $\mathrm{J} / \mathrm{cm}^{2}$ followed by $950^{\circ} \mathrm{C} 150$ s RTA. Positions of the $\mathrm{E}_{-}$and $\mathrm{E}_{+}$transitions as well as the energy levels of the conduction band minimum of the substrate $\mathrm{E}_{\mathrm{M}}$ and the $\mathrm{N}$ level $\mathrm{E}_{\mathrm{N}}$ are also indicated in the figure.

Fig. 2 Measured values of the $\mathrm{E}_{-}$and $\mathrm{E}_{+}$transitions in GaNAsP are shown as closed and open circles, respectively. The solid curves show the positions of the conduction band minimum at the $\Gamma$ point $\mathrm{E}_{\mathrm{M}}$ for the $\mathrm{GaAs}_{1-\mathrm{y}} \mathrm{P}_{\mathrm{y}}$ substrate and the $\mathrm{N}$ level $\mathrm{E}_{\mathrm{N}}$. Calculated values of the $\mathrm{E}_{\text {. }}$ and $\mathrm{E}_{+}$transitions based on the BAC model for $\mathrm{x}=0.003,0.01$ and 0.02 are also shown. 


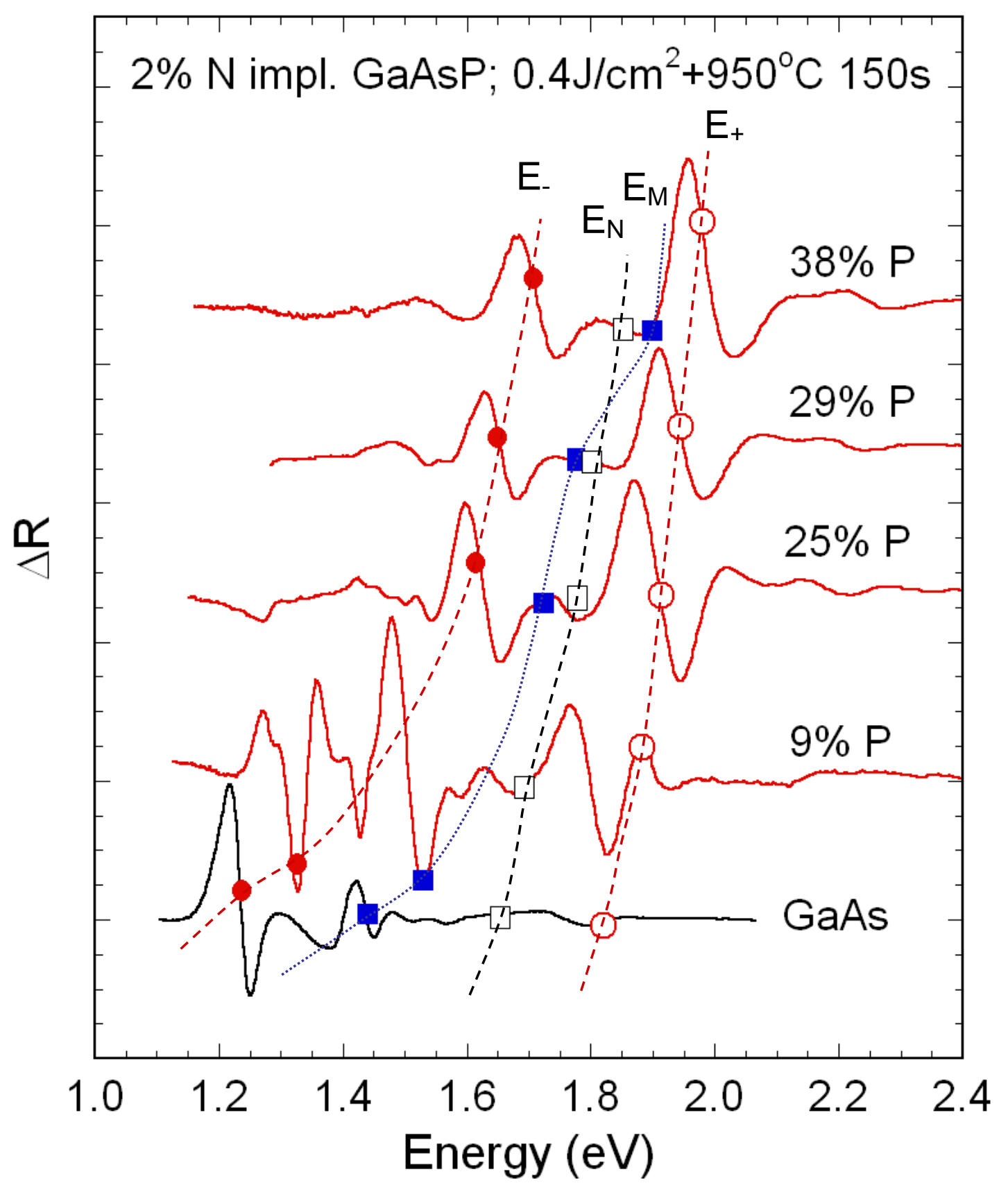

Fig. 1 


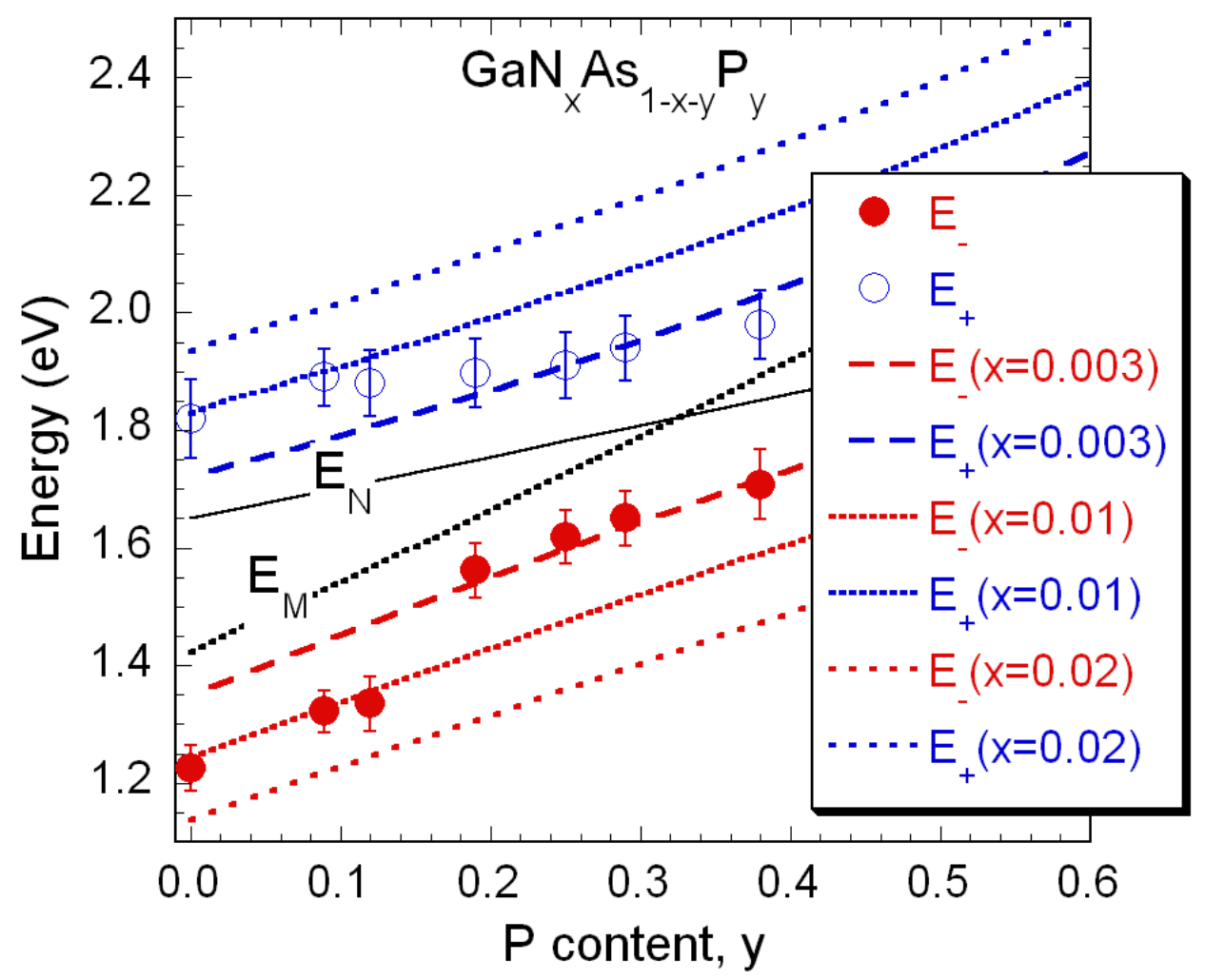

Fig. 2 